\title{
Assessment of Heavy Metals Concentration in Shore Sediments from the Bank of River Benue, North-Central Nigeria
}

\author{
Ejembi Emmanuel1, Terver Sombo², Jonathan Ugwanyi² \\ ${ }^{1}$ Department of Natural and Applied Sciences, Namibia University of Science and Technology, Windhoek, Namibia \\ ${ }^{2}$ Department of Physics, University of Agriculture, Makurdi, Nigeria \\ Email: emmy2save@yahoo.com
}

How to cite this paper: Emmanuel, E., Sombo, T. and Ugwanyi, J. (2018) Assessment of Heavy Metals Concentration in Shore Sediments from the Bank of River Benue, North-Central Nigeria. Journal of Geoscience and Environment Protection, 6, 35-48.

https://doi.org/10.4236/gep.2018.64003

Received: January 26, 2018

Accepted: March 30, 2018

Published: April 2, 2018

Copyright (๑) 2018 by authors and Scientific Research Publishing Inc. This work is licensed under the Creative Commons Attribution International License (CC BY 4.0).

http://creativecommons.org/licenses/by/4.0/ (c) (i) Open Access

\begin{abstract}
Heavy metals are elements, whose density is greater than water. They are generated from our environment. Rocks, sediments, plants, water and aerosol particles represent the carriers of heavy metals. An accumulated amount of heavy metal in the body, either by inhalation, food or drinking water, can cause an adverse health effect to human. The Benue river passed through the town of makurdi, was high population of the inhabitant of Benue State dwells. The industrial and agricultural activities carried out in this region, increase the concentration of heavy metals. This may result to adverse health effect on the inhabitant of Makurdi. The objectives of this work were to determine the heavy metal concentration and its site contaminations along the bank of river Benue, Makurdi. An inductively coupled plasma optical emission spectrometry (ICP-OES) was used to determine the heavy metals concentration. The metals concentrations (Iron, Copper, Manganese, Lead, Zinc, Chromium, Arsenic, and Cadmium) of the three stations were found. This ranges from 3.55 $9454.0 \mathrm{mg} / \mathrm{kg}, 0.20-8928.0 \mathrm{mg} / \mathrm{kg}$ and $2.80-13,657 \mathrm{mg} / \mathrm{kg}$ for stations 1,2 and 3. With Fe recorded as the highest concentration in the sediment, this value is compared with the World Health Organisation (WHO) and World Surface Rock Average (WSRA) standard. The assessment on contamination status of heavy metals in the riverbank, showed low degree of contamination in stations 1 and 2, and moderate degree in station 3. The degree of enrichment to heavy metals in all the stations is deficient to minimal. The evaluation of the results of pollution load index (PLI) from this present study indicated PLI $<1$ for station 2, and PLI $>1$ in stations 1 and 3 . Hence stations 1 and 3 are polluted, while station 2 is not polluted with heavy metals.
\end{abstract}

\section{Keywords}

Heavy Metals, Site Contamination Parameter, ICP-OES 


\section{Introduction}

Heavy metals can be defined as metals with densities that are five times higher than water. They are formed naturally from the terrestrial environments, and they are found in rocks, plants, soils and sediments. Human and industrial activities can increase the amount of heavy metals concentration in the environments and lead to environmental pollution [1]. However, the contamination of heavy metals in surface soil, water, air and sediments can cause an adverse health effect on human and the environment [2]. The aim of this work was to measure the level of heavy metals in shore sediments and also their activity concentration trend along the bank of river benue, Makurdi. The heavy metal concentrations in the shore sediments were also compared, with guideline limit upon which informed decision about the site quality was made. In this paper, we assessed the site contamination using the criteria of Enrichment Factor (EF), Contamination factor (CF) and Pollution load index (PLI).

\section{Geologic Background}

The sediment geochemical quality in an urban environment depends not only on the concentration of pollution sources, but also on time-span of urbanization, industrialization and poor agricultural practices. The high concentration of heavy metals in the environments can be found in the developed countries, while the low concentration can be found in developing countries (e.g., Africa). However, the threat of heavy metals pollution may depend on the increases in urbanization and social economics activities, [3]. Suspended sediments found in water, absorb heavy metals from the water column. This helps to reduce the amount of heavy metals found in the water. Although, these metals are released into the water, by different human activities, they by causing a potential threat to ecosystems [4].

Sediments are important carriers of heavy metals, whereas large amounts of heavy metals are accumulated in river, ocean and sea sediments, where they get incorporated onto clays and other shore fine-grained materials. However, the sediments can release heavy metals into the overlying water, thereby causing potential adverse effects to the ecosystems. Heavy metals found in sea and river surface, are deposited in sediment and aquatic plant. Over the last few years, heavy metals have increased enormously into the environment from artificial sources. Because of its health risk, they are a lot of awareness that has been done on the effect of this heavy metals to human. Suspended air particle containing heavy metal can damage tissue, when inhaled. Heavy metal concentrations generated from anthropogenic source (e.g., $\mathrm{Cd}, \mathrm{As}, \mathrm{Pb}, \mathrm{Cu}, \mathrm{Fe}, \mathrm{Zn}, \mathrm{Mn}$, and $\mathrm{Cr}$ ) to coastal environment can cause a potential risk to the natural environment. Therefore, it is important to assess and tract the abundance of these heavy metals in coastal ecosystem [5].

An elevated concentration of heavy metals increases the potential of adverse 
health effects to inhabitants in each environment [6]. Some common health effects associated with heavy metal poisoning include blindness, organ damage and breathing related problems [7]. The toxicity of heavy metals depends on their chemical form and the species of the elements. For some metals, the most toxic form is that having alkyl groups attached to the metal since most of such compounds are soluble in animal tissues and can pass through biological membranes. For example, the uptake of arsenic can cause skin lesions, neurotoxicity and other cancerous problems of different form. Cadmium (Cd) has high soil mobility than any other metal to plant system. In human, only about 5\%-50\% of the inhaled element ever enters the lungs. Also, only $1 \%-10 \% \mathrm{Cd}$ gets into the digestive system via ingestion of food and water intake. Chronic exposures to $\mathrm{Cd}$ result in renal tubular damage, bone deformities, and heart related diseases [8]. Nickel is among non-essential element needed for the healthy growth of plants, animals and soil microbes. It interacts with iron found in hemoglobin and helps in oxygen transport, stimulate the metabolism as well as being regarded as a key metal in several plants and animal's enzyme systems. $\mathrm{Ni}$ is readily transported from the roots to over ground plant tissues. However, at higher concentrations, it can be toxic. Ingestion and inhalation of high levels of nickel (Ni) induce lung damage in man, Ni dermatitis is the most common effect of the element of human population [9]. Mercury ( $\mathrm{Hg}$ ) comes under the class of metallic poisons. At room temperature, the metal is in liquid form. Although metallic mercury is not poisonous, but it causes poisoning when inhaled in its vapor form, swallowed or rubbed into the skin. The toxicity of mercury depends on its chemical form and route of exposure. It affects the immune system, alters genetic and enzyme systems, and damages the nervous system, including incoordination and the textile, and visual hallucinations [10].

Zinc plays a very important role in plant nutrition, it has been a component of a number of metalo-enzymes. Zinc is an essential beneficial element of human beings, but their element salts produce undesirable taste to water. It is discharged into sewage and soils from pharmaceutical paints, pigment, several insecticides and cosmetic industry. Although $\mathrm{Zn}$ has been found to have low toxicity to man, prolonged consumption of large doses can result in some health complications such as fatigue, dizziness, and neutropenia [11]. Excessive and prolonged inhalation of $\mathrm{Mn}$ particulate in mining, welding and industries results in its accumulation in selected brain regions that causes central nervous system (CNS) dysfunctions and an extrapyramidal motor disorder, a recent report suggested that, some aspects of disease may also occur in individual, because of exposure from environmental source [12]. $\mathrm{Cu}$ are metallic elements that can be released to the environment through mining, smelting and refining of copper. Acute exposure of $\mathrm{Cu}$ can lead to $\mathrm{Cu}$ poisoning, such as flu like condition known as metal fever, vomiting, diarrhea, stomach cramps, and nausea. Chronic exposure can result to brain damage, demyelization, renal disease and copper deposition in the cornea and even death [13]. 


\section{Materials and Methods}

The present study focuses on three locations that are located at the bank of river Benue, Makurdi the Capital of Benue State. Benue State is located at the north central part of Nigeria, between latitudes $7^{\circ} 35^{\prime}-7^{\circ} 53^{\prime} \mathrm{N}$ and longitudes $8^{\circ} 24^{\prime}$ $8^{\circ} 42^{\prime} \mathrm{E}$. The city of Makurdi covers a land area of $800 \mathrm{~km}^{2}$ and has a population of 300,000 people (2006 census data). The city lies entirely in the flood plans of Benue River, which bisects the city into northern and southern parts [14]. Human activity, such as irrigation farming, extraction of sediment, such as shape sand for building, fishing, and market activity are carried out, along the bank of the river Benue, Makurdi. The research was carried out at the new bridge, new garage and wadata market river bank, known as station 1, 2 and 3. Figure 1 represents the map of Makurdi, Benue State showing the study areas [15]. The techniques mentioned below were used to achieve the objectives of the present work.

\subsection{Samples Collection and Pre-Treatments for Heavy Metals}

Samples collected from the studied areas were mixed, to ensure even distribution. The samples were then filtered to a certain size (e.g., $1 \mathrm{~mm}$ mesh) that contains high level of heavy metal [16]. Three sub-samples were taken from the large sieved samples and transferred into clean pre-labelled plastic containers, which were labelled as station 1, 2 and 3. Station 1 is the mixed samples of new bridge river bank (NBRB). Station 2 is the mixed samples of new garage river bank (NGRB) locations and station 3 is the mixed samples of

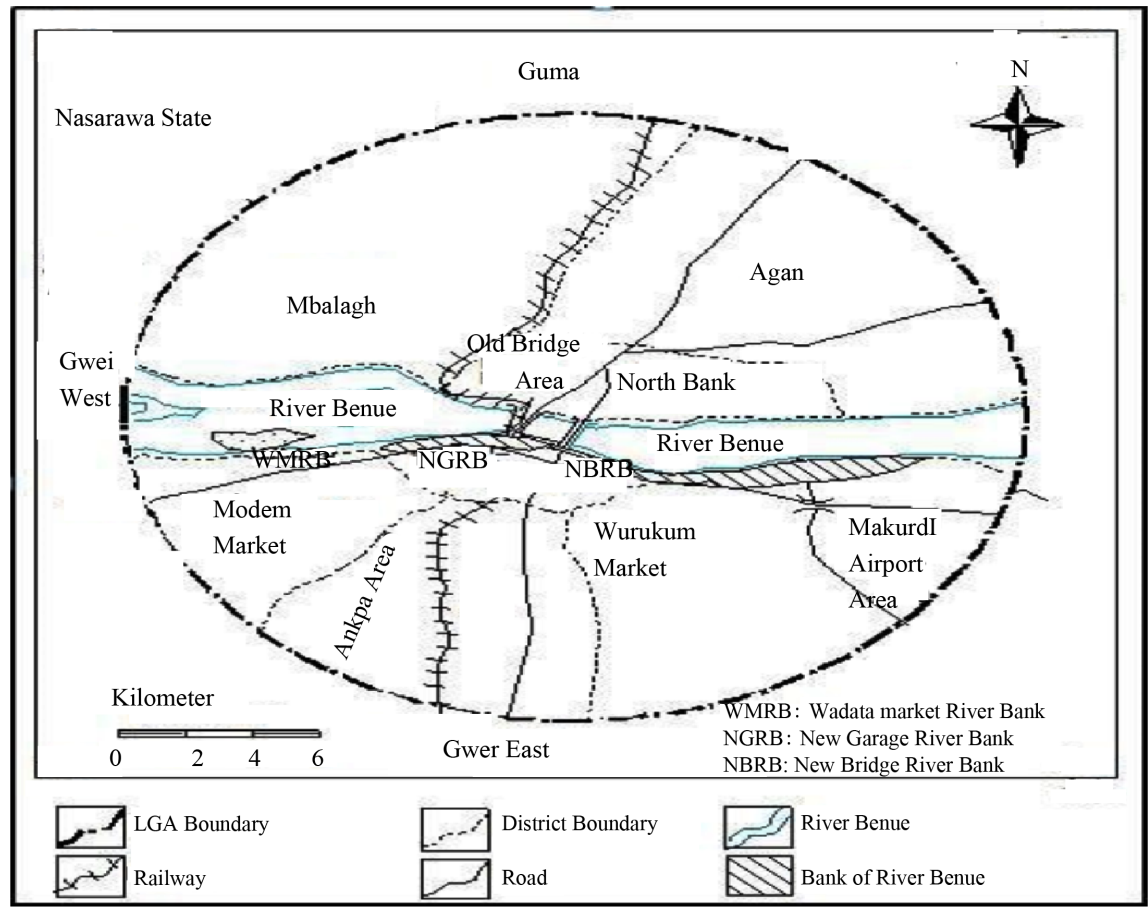

Figure 1. Map of Makurdi, Benue State. Showing the study areas. 
wadata market river bank (WMRB) locations. The samples are, subsequently, transported to Analytical Laboratory Services, Windhoek Namibia, for further processing and analyses. All materials used for holding samples, homogenization and sieving were pre-cleaned with $10 \%$ nitric acid to minimize the potential of cross contamination.

The samples were digested according to the reported environmental protection agency (EPA) method 3050B for Inductively Coupled Plasma-Optical Emission Spectrophotometer (ICP-OES) analysis [17]. A known amount (1.00 g) of each sample was transferred into a digestion vessel and $10 \mathrm{~mL}$ of $1: 1$ nitric acid $\left(\mathrm{HNO}_{3}\right)$ was added, mixed thoroughly and covered with a watch glass. Subsequently, the samples were heated to $90^{\circ} \mathrm{C}$ and refluxed at this temperature for 10 minutes, after which they were allowed to cool for 5 minutes under room temperature. Thereafter, $5 \mathrm{ml}$ of concentrated $\mathrm{HNO}_{3}$ was added to each, covered and refluxed again at $90^{\circ} \mathrm{C}$ for 30 minutes. Then, the solution was allowed to evaporate without boiling to approximately $5 \mathrm{ml}$ each and cooled again for 5 minutes. This was followed by the addition of $2 \mathrm{ml}$ of deionised water plus $3 \mathrm{ml}$ of $30 \%$ hydrogen peroxide $\left(\mathrm{H}_{2} \mathrm{O}_{2}\right)$ to each. The vessels were covered and heated just enough to warm the solutions for the peroxide reaction to start. This was continued until effervescence subsided and the solutions were cooled. The acid-peroxide digest was covered with watch glasses and heated until the volume reduced to approximately $5 \mathrm{ml}$ again. Thereafter, $10 \mathrm{ml}$ of concentrated hydrochloric acid $(\mathrm{HCl})$ was added to each, covered and heated on a heating mantle, then refluxed at $90^{\circ} \mathrm{C}$ for 15 minutes. After cooling, each digest was filtered through Whatman No. 41 filter paper into a $100 \mathrm{ml}$ volumetric flask and the volume made to the mark with deionised water [18].

Ten $\mathrm{ml}$ of each digest was taken and mixed with equal volume of matrix modifier [18], and then analysed using ICP-OES (ICP: Perkin Elmer Optima 7000 DV) housed in analytical laboratory Windhoek, Namibia for the levels of arsenic, cadmium, chromium, lead, manganese, iron, copper, zinc and nickel. Data generated from quadruplicate analyses were expressed as the mean concentration of each element.

\subsection{Heavy Metals Site Contamination Parameters}

Heavy metal site contamination can be assessed using the following parameter: Enrichment Factor (EF), Contamination factor (CF) and Pollution load index (PLI).

The CF gives an indication of the degree of contamination of soil. The level of contamination factor of sediment by metal is expressed by Equation (1). $C_{\text {Sample }}$ is the given metal in shore sediment, $C_{\text {Background }}$ is the background value of the metal [19]. The $C_{\text {Background }}$ value equals to the world surface rock average.

$$
\mathrm{CF}=\frac{C_{\text {Sample }}}{C_{\text {Background }}}
$$


The Enrichment Factor is defined as a factor used in assessment of the degree of contamination with heavy metal. [19]. Equation (2) below represents the EF.

$$
\mathrm{EF}=\frac{\mathrm{C} / \mathrm{Fe}(\text { sample })}{\mathrm{C} / \mathrm{Fe}(\text { earth crust })}
$$

where $\mathrm{C} / \mathrm{Fe}$ (sample) is the content of the examined and the reference element in the examined locations, $\mathrm{C} / \mathrm{Fe}$ (earth crust) is the content of the examined and reference element in the reference environment (World Surface Rock Average) (WSRA).

Pollution load index (PLI) is used in evaluating the pollution level in an environment [5]. Given in Equation (4).

$$
\mathrm{PLI}=\left(\mathrm{CF}_{1} \times \mathrm{CF}_{2} \times \mathrm{CF}_{3} \times \cdots \times \mathrm{CF}_{n}\right)^{1 / n}
$$

where, $\mathrm{CF}$ is the contamination factor and $\mathrm{n}$ is the number of metals investigated. If PLI value is $>1$ it means polluted, while PLI value $<1$ indicates no pollution.

\section{Results}

\subsection{Assessment of Metal Concentration}

The heavy metals investigated in this study include arsenic (As), cadmium (Cd), chromium $(\mathrm{Cr})$, lead $(\mathrm{Pb})$, manganese $(\mathrm{Mn})$, iron $(\mathrm{Fe})$, copper $(\mathrm{Cu})$ and zinc $\mathrm{Zn})$. These metals were determined from the sediments collected from the bank of river Benue. The locations are combined to form station 1 (NBRB), station 2 (NGRB) and Station 3 (WMRB).

Heavy metals concentration present in sediment samples of the bank of river Benue, were measured and analyzed. The spatial variation in the mean values of their concentration and comparison with reference values of World Surface Rock Average (WSRA) and World Health Organization (WHO) is shown in Table 1. The heavy metals concentrations for each station are presented in bar chart, as shown in Figures 2-4.

The concentration of heavy metals in station 1 ranged from 3.55 to 9454.0 $\mathrm{mg} / \mathrm{kg}$, (Figure 2). The highest value was that of $\mathrm{Fe}$ and the lowest one was that of Cd. In station 2, the concentration ranged from $0.20 \mathrm{mg} / \mathrm{kg}$ to $8928.0 \mathrm{mg} / \mathrm{kg}$ and $\mathrm{Fe}$ was highest $(8928.0 \mathrm{mg} / \mathrm{kg})$, while $\mathrm{Cr}$ and As metals have the lowest concentration $(0.20 \mathrm{mg} / \mathrm{kg})$ (Figure 3). That of station 3, ranged from $2.80 \mathrm{mg} / \mathrm{kg}$ to $13657.0 \mathrm{mg} / \mathrm{kg}$, and has the highest concentration of Fe $(13657.0 \mathrm{mg} / \mathrm{kg})$ than that of the other stations, and it has a low concentration of Cd $(2.80 \mathrm{mg} / \mathrm{kg})$, (Figure 4). The results obtained showed that Fe recorded the highest concentration in all the sites investigated. This may be because of its natural sources (1.5\%) vastly dominate its input [5].

Table 1 shows the various concentration of heavy metals, the concentration of the $\mathrm{Cd}$ in the sediments ranged from 1.85 to $2.80 \mathrm{mg} / \mathrm{kg}$ and followed the order station $3>$ station $1>$ station 2 . Chromium $(\mathrm{Cr})$ is found to ranged from 
Table 1. Concentration of heavy metals along the bank of river Benue represent the used reference values [20].

\begin{tabular}{cccccc}
\hline Heavy metals (mg/kg) & $\begin{array}{c}\text { Station 1 } \\
\text { (NBRB) }\end{array}$ & $\begin{array}{c}\text { Station 2 } \\
\text { (NGRB) }\end{array}$ & $\begin{array}{c}\text { Station 3 } \\
\text { (WMRB) }\end{array}$ & WHO & WSRA \\
\hline As & 3.55 & 0.20 & 15.85 & 20.0 & 10.0 \\
$\mathrm{Cd}$ & 2.10 & 1.85 & 2.80 & 3.0 & 0.3 \\
$\mathrm{Cr}$ & 3.55 & 0.20 & 15.50 & 100.0 & 71.0 \\
$\mathrm{~Pb}$ & 102.0 & 46.0 & 17.0 & 100.0 & 16.0 \\
$\mathrm{Mn}$ & 145.5 & 75.0 & 253.5 & 2000.0 & 750.0 \\
$\mathrm{Fe}$ & 9454.0 & 8928.0 & 13657.0 & 5000.0 & 300.0 \\
$\mathrm{Cu}$ & 293.0 & 84.50 & 118.0 & 100.0 & 32 \\
$\mathrm{Zn}$ & 18.00 & 14.00 & 27.00 & 300.00 & 127.0 \\
\hline
\end{tabular}

Note: World Surface Rock Average (WSRA) and World Health Organization (WHO).

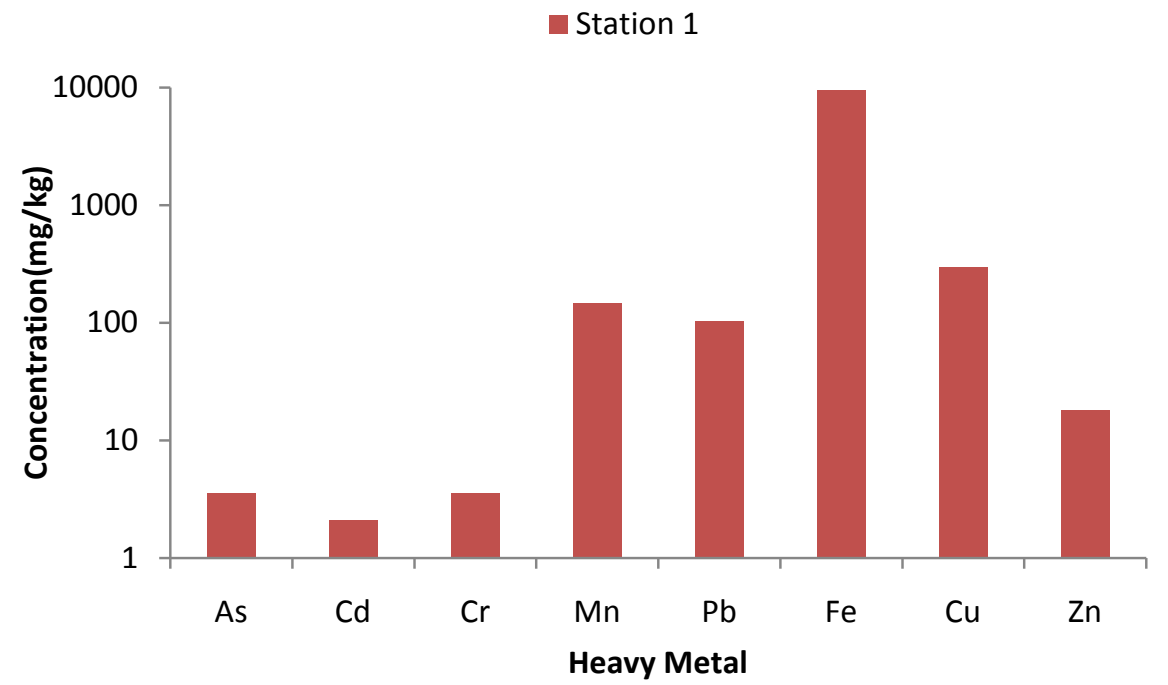

Figure 2. Bar chart showing the concentration of heavy metals in station 1 (NBRB).

Station 2

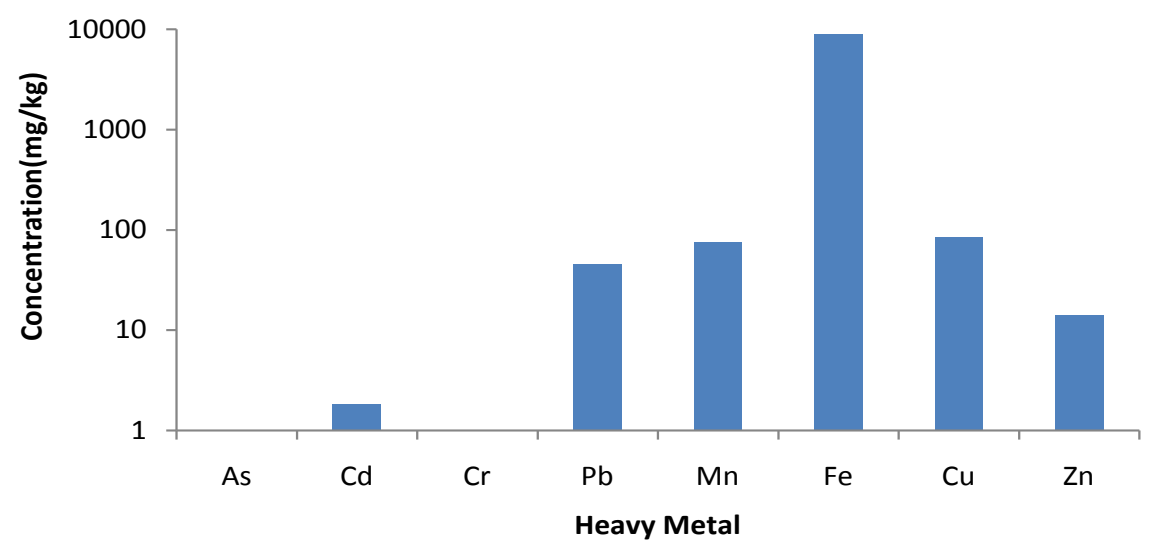

Figure 3. Bar chart showing the concentration of heavy metals in station 2 (NGRB). 


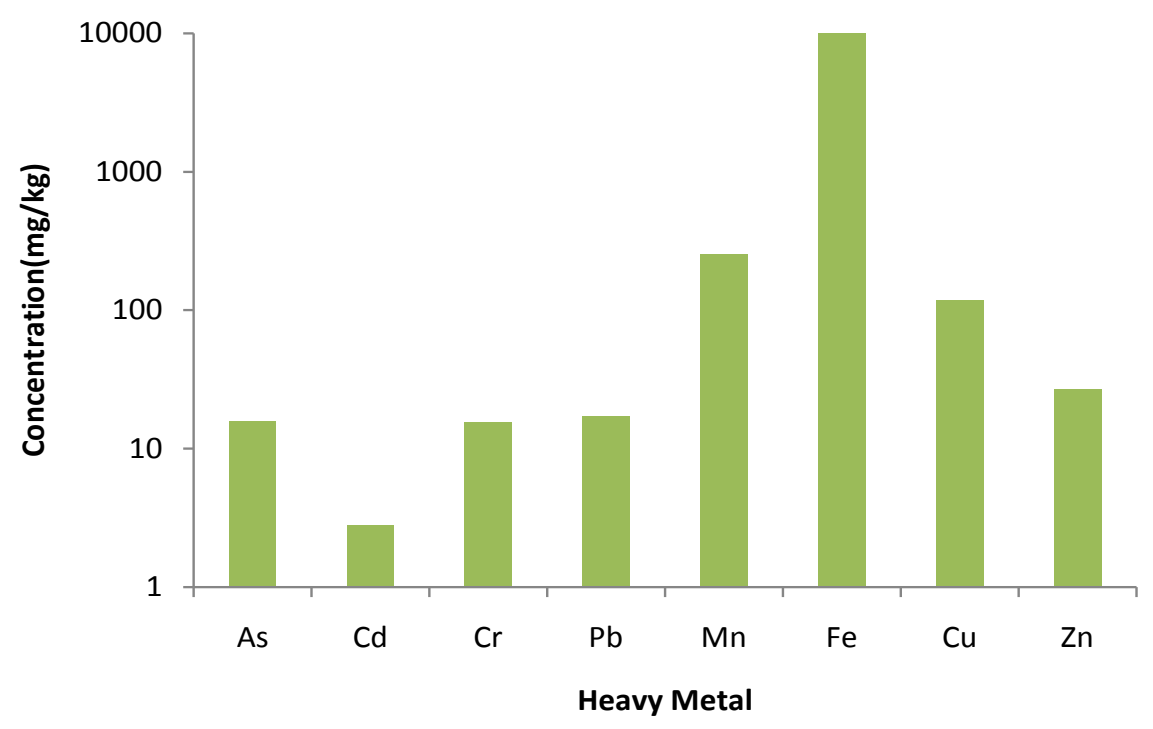

Figure 4. Bar chart showing the concentration of heavy metals in station 3 (WMRB).

0.20 to $15.50 \mathrm{mg} / \mathrm{kg}$. it concectration, decreased in the order station $3>$ station $1>$ station 2 . The concentration of lead $(\mathrm{Pb})$ in sediment samples ranged from 17.0 to $102.0 \mathrm{mg} / \mathrm{kg}$. The concentration of lead decreased in order of station $1>$ station $2>$ station 3. Manganese concentrations ranged from $75.0 \mathrm{mg} / \mathrm{kg}$ to $253.5 \mathrm{mg} / \mathrm{kg}$. The concentration of Manganese decreased in order of station $2>$ station $1>$ station 3. The WHO maximum permissible level in soil is 2000 $\mathrm{mg} / \mathrm{kg}$. Zinc concentration ranges from $14.0 \mathrm{mg} / \mathrm{kg}$ to $27.0 \mathrm{mg} / \mathrm{kg}$ in the sediment, its concentration decreases in order of station $3>$ station $1>$ station 2 .

\subsection{Assessment of Site Contamination}

It is relevant to compare heavy metal concentrations in sediment with their guideline limit values upon which informed decision about the site quality could be made. In this study, site contamination was assessed using the criteria of Enrichment Factor (EF), Contamination factor (CF) and Pollution load index (PLI) as explained in the literature. The contamination factor, Enrichment Factor (EF) and pollution load index of the heavy metals was calculated, using Equation (1), (2) and (4) from the literature, as shown in Tables 2-4.

The values of the CF for the three stations are presented in Table 2 and Figure 5. The contamination criteria based on contamination factor was proposed by Foley et al., [19]. The present study showed that the CF values in stations 1,2 and 3 range from $(0.050-31.513),(0.003-29.760)$ and $(0.213-45.523)$ respectively.

Table 3 and Figure 6, show the values for the enrichment factor, which range from 0.0045 to 1.5864 at station 1, from 0.0001 to 0.2072 at station 2 and from 0.0048 to 0.2050 at station 3 . The degrees of enrichment to heavy metals in all the stations are deficient to minimal, because all the values are less than two. 


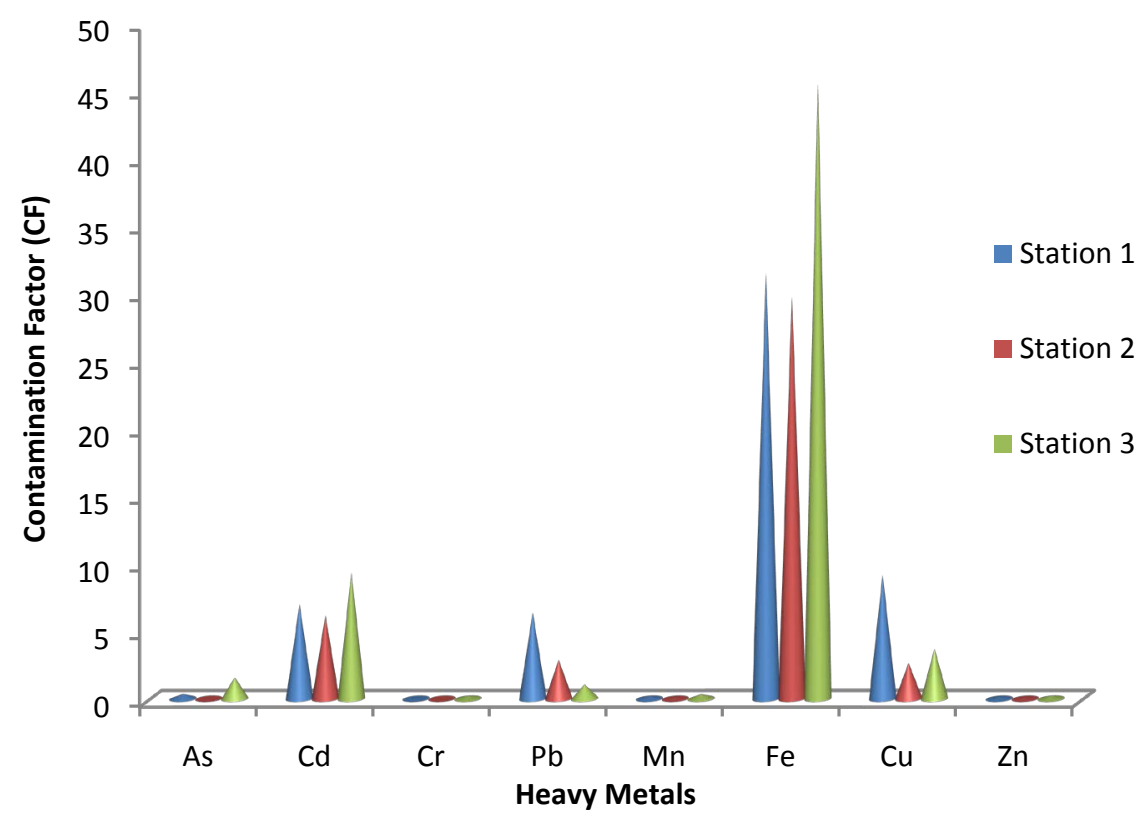

Figure 5. Contamination Factor (CF) of heavy metals in the three stations along the bank of river Benue.

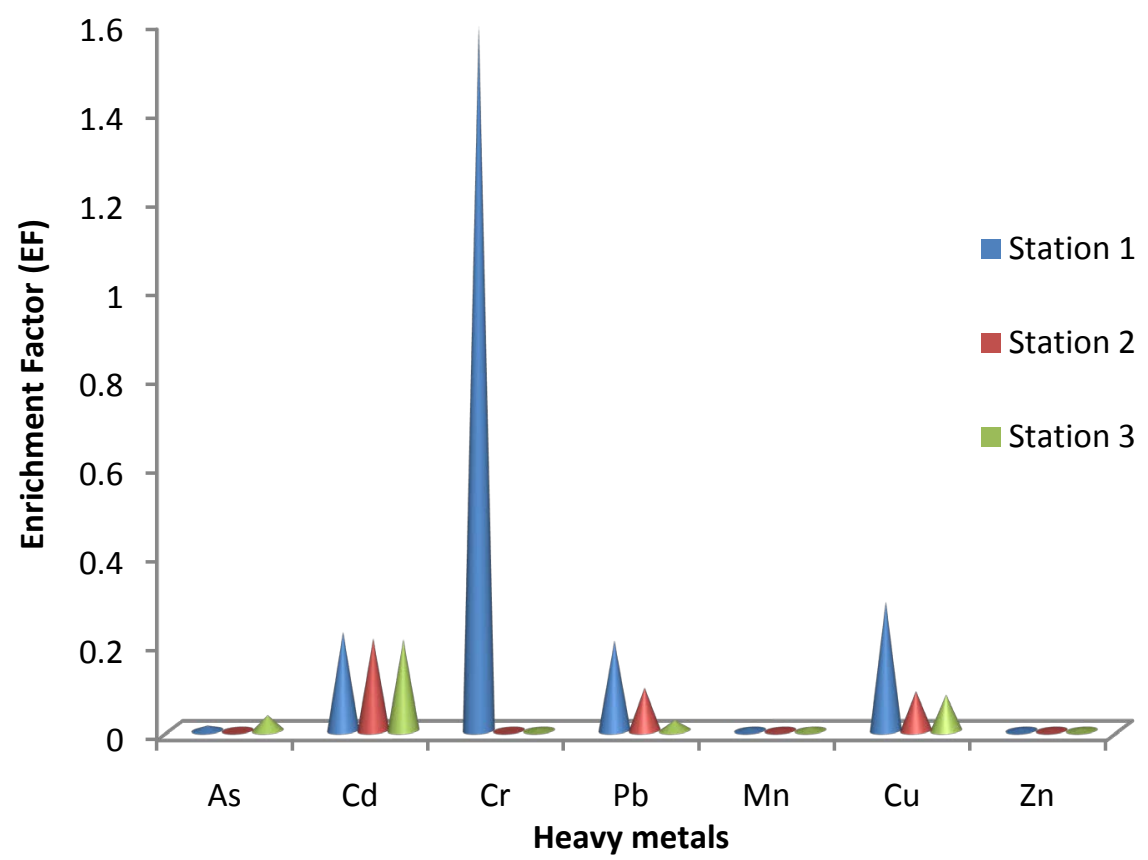

Figure 6. Enrichment Factor (EF) of heavy metals in the three stations along the bank of river Benue.

This implies that, the fractions of element entry into the metals from artificial source are very minimal. The EF of this present study was compared with the study carried out at copper-nickel mine in the Selebi Phikwe region, Eastern Botswana, which values range from $0.75-8.57,0.50-5.20,0.66-11.44$ and 0.28 - 4.17 in method A, B, C and D [21]. Seasonal enrichment factor (EF) of heavy 
Table 2. Contamination Factor (CF) of heavy metals along the bank of river Benue.

\begin{tabular}{cccc}
\hline Heavy metals & $\begin{array}{c}\text { Station } 1 \\
\text { (NBRB) }\end{array}$ & $\begin{array}{c}\text { Station 2 } \\
\text { (NGRB) }\end{array}$ & $\begin{array}{c}\text { Station 3 } \\
\text { (WMRB) }\end{array}$ \\
\hline $\mathrm{As}$ & 0.355 & 0.020 & 1.585 \\
$\mathrm{Cd}$ & 7.000 & 6.170 & 9.330 \\
$\mathrm{Cr}$ & 0.050 & 0.003 & 0.218 \\
$\mathrm{~Pb}$ & 6.375 & 2.875 & 1.063 \\
$\mathrm{Mn}$ & 0.194 & 0.100 & 0.338 \\
$\mathrm{Fe}$ & 31.513 & 29.760 & 45.523 \\
$\mathrm{Cu}$ & 9.156 & 2.641 & 3.688 \\
$\mathrm{Zn}$ & 0.142 & 0.110 & 0.213 \\
\hline
\end{tabular}

Table 3. Enrichment Factor (EF) of heavy metals along the bank of river Benue.

\begin{tabular}{cccc}
\hline Heavy metals & $\begin{array}{c}\text { Station 1 } \\
\text { (NBRB) }\end{array}$ & $\begin{array}{c}\text { Station 2 } \\
\text { (NGRB) }\end{array}$ & $\begin{array}{c}\text { Station 3 } \\
\text { (WMRB) }\end{array}$ \\
\hline $\mathrm{As}$ & 0.0110 & 0.0007 & 0.0349 \\
$\mathrm{Cd}$ & 0.2221 & 0.2072 & 0.2050 \\
$\mathrm{Cr}$ & 1.5864 & 0.0001 & 0.0048 \\
$\mathrm{~Pb}$ & 0.2024 & 0.0967 & 0.0233 \\
$\mathrm{Mn}$ & 0.0062 & 0.0034 & 0.0074 \\
$\mathrm{Cu}$ & 0.2904 & 0.0887 & 0.0809 \\
$\mathrm{Zn}$ & 0.0045 & 0.0037 & 0.0048 \\
\hline
\end{tabular}

Table 4. Pollution Load Index (PLI) of heavy metals along the bank of river Benue.

\begin{tabular}{cccc}
\hline & $\begin{array}{c}\text { Station 1 } \\
(\mathrm{NBRB})\end{array}$ & $\begin{array}{c}\text { Station 2 } \\
\text { (NGRB) }\end{array}$ & $\begin{array}{c}\text { Station 3 } \\
\text { (WMRB) }\end{array}$ \\
\hline PLI & 1.2586 & 0.4173 & 1.5928 \\
\hline
\end{tabular}

metals, obtain from Erongo region, ranges from 0.4240 - 27.8943, 0.2615 $8.3683,0.2593-0.2702$ and $0.4240-22.3155,0.2965-19.5260,0.2455-27.8943$, during summer and winter. This work was carried out by [5], in Walvis Bay, Swakopmund and Hentis Bay beach, and was compared with this present study.

The pollution load index (PLI) was calculated using Equation (4) and data in Table 2, as shown in Table 4. If PLI value is $>1$ it means polluted while PLI value $<1$ indicates no pollution. The PLI values decreased in the order of station $3>1>2$ (Figure 7) The studies showed that the PLI ranged from 0.4173 to 1.5928. The highest index of pollution load was calculated for station 3 and the lowest value was calculated for station 2 .

\section{Discussion}

All over the globe, contaminations are washed into rivers, coastal regions and estuarines from industrial activities. Among some of those contaminant, heavy 


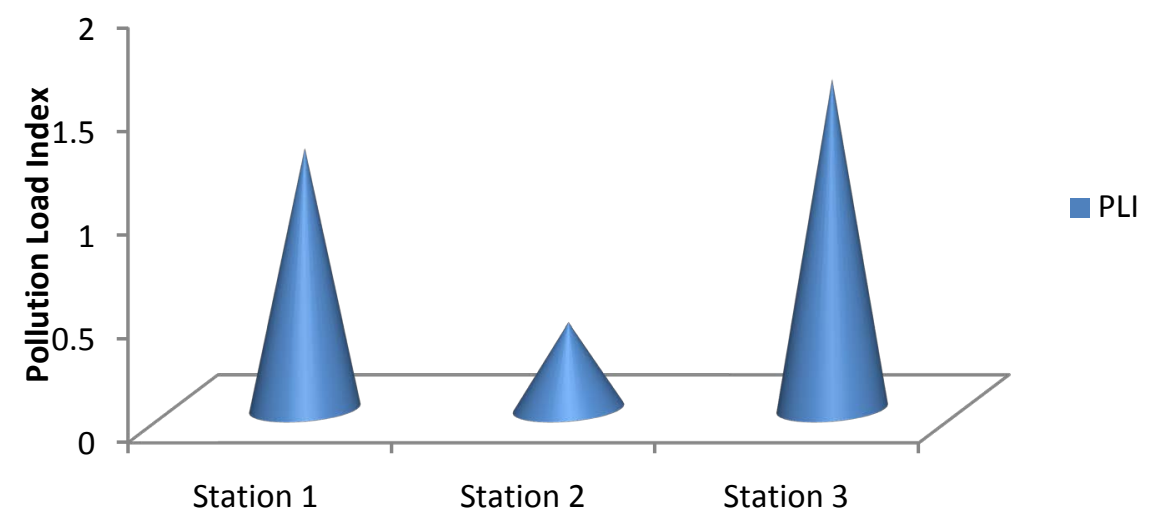

Figure 7. Pollutions load index (PLI) of heavy metals in the three stations along the bank of river Benue.

metals are serious pollutant of the aquatic environments. Heavy metals found in plant and animal, can cause harmful effect to human health, when taking in as food. [22]. This metal is carcinogenic and is usually taken by inhalation; it is also, corrosive to tissue. It is used in alloys, electroplating, pigments, paint manufacture, fungicides, glass, leather tanning industries and photography [23].

The study showed that the concentration of arsenic is below the referenced values of WHO in station 1, 2 and 3, and also below WSRA in station 1 and 2. But the concentration of arsenic in station 3 is above WSRA. Cadmium is slightly below the reference value (WHO) and far greater than the reference value of (WSRA). The permissible limit of Cd in soil, recommended by WHO, is $3.0 \mathrm{mg} / \mathrm{kg}$ (Table 1). The three stations did not exceed the standard and are therefore not polluted according to EPA guideline and it was quite high compared with the values recorded by Onjefu et al., [5]. Cr concentrations in the three stations are below the reference value. According to the EPA guideline for heavy metal in sediment, the sampled sites are unpolluted with chromium. The values recorded during this investigation were lower for station 1,2 and higher in station 3. The values are compared to similar studies undertaken by Onjefu et al. [5], However, these concentrations of $\mathrm{Cr}$ were higher than the levels of 0.25 to $1.68 \mathrm{mg} / \mathrm{kg}$ in the Benin River, Nigeria [24]. The concentration of lead recorded was above WSRA and indicates that the region of station 1 is heavily polluted, station 2 and 3 are moderately polluted according to EPA heavy metal guidelines for sediments (Table 1). Lead $(\mathrm{Pb})$ as a soil contaminant is a global issue; it accumulates with age in bones, aorta, kidneys, spleen and liver. This metal can enter the body through uptake of food, water and air. The concentration of lead in this study was higher than the values ( 11.8 to $39 \mathrm{mg} / \mathrm{kg}$ and 14.0 to $22.1 \mathrm{mg} / \mathrm{kg}$ ) obtained by Saikia et al., [25] and in the sediments of the Subansiri River respectively. Manganes (Mn) is essential for plant and animals, but an elevated level can pose threat to life. Mn investigated in this study was quite high compared with the concentration recorded by Onjefu et al., [5]. The value of $\mathrm{Zinc}(\mathrm{Zn})$ in 
all the station is less compared to the WHO maximum permissible level $(300.0$ $\mathrm{mg} / \mathrm{kg}$ ) and the WSRA value $(127 \mathrm{mg} / \mathrm{kg})$, according to EPA heavy metal Guidelines for sediment.

The degree of contamination in station 1 and 2 indicate low degree and moderate degree in station 3. $\mathrm{Cr}, \mathrm{Mn}$ and $\mathrm{Zn}$ indicate a low degree of contamination in all the stations. $\mathrm{Cd}, \mathrm{Fe}$ and $\mathrm{Cu}$ indicate a high degree of contamination, except for station 2 were Fe has a moderate degree. The high degree of contamination of $\mathrm{Cd}, \mathrm{Mn}$ and $\mathrm{Cu}$ in station 3 may be as a result of refuge dump around the bank of the river. $\mathrm{Pb}$ has a high degree of contamination in station 1 and a moderate degree of contamination in both stations 2 and 3. These values are in contrast with similar studies [26] where As is of concern and Cd has a low degree of contamination. The EF value of this present study was less compared to the study of heavy metal around a copper-nickel mine in the Selebi Phikwe region, Eastern Botswana, and seasonal enrichment factor (EF) of heavy metals, obtain from Erongo region as explained in the result.

The PLI investigated in this study was quite high compared with the values recorded by Onjefu et al., [5]. In their studies, the PLI ranges from 0.0660 to 0.2097 . The PLI values presented in Table 4 clearly indicated values $<1$ for stations 2 , and $>1$ in stations 1 and 3. Hence, according to Tomlinson et al., [27] station 1 and station 3 are polluted with heavy metals, while station 2 are not polluted with heavy metals.

\section{Conclusion}

The results of this study revealed the presence of lead, chromium, cadmium, arsenic, copper, iron, zinc and manganese in the sediment of river Benue area of Makurdi, and their various concentrations in each station were specified. This showed that iron $(\mathrm{Fe})$ has the highest concentration in all the stations, which is higher than the permissible level of WHO and WSRA. The concentrations of copper and manganese are higher in the sediment compared to the other metals like lead, chromium, cadmium, arsenic and zinc. According to EPA guidelines for sediment, it is shown that iron is heavily polluted in the sediment. Cadmium, Chromium, Manganese and Zinc are not polluted, while lead is moderately polluted. The site contamination of heavy metals evaluated in this study shows that the contamination degree of heavy metal varies in the stations. This variation occurs because of human and industrial activities conducted in those areas. The degree of enrichment of heavy metals in the all stations is deficient to minimal, this is because all the value is less than two. From the pollution index evaluation, it is indicated that station 1 and station 3 are polluted with heavy metals, while station 2 is not polluted.

\section{Acknowledgements}

We appreciate the Analytical Laboratory Services Windhoek, Namibia, for assisting us with the test Analysis. 


\section{References}

[1] Ubwa, S.A. (2013) Levels of Some Heavy Metals Contamination of Street Dust in the Industrial and High Traffic Density Areas of Jos Metropolis. Journal of Biodiversity and Environmental Sciences, 3, 13-21.

[2] Li, Y., Hong, Y.T., Wang, D.J. and Zhu, Y.X. (2007) Determination of Free Heavy Metal Ion Concentrations in Soils around a Cadmium Rich Zinc Deposit. Geochemical Journal, 41, 235-240.

[3] Ogoyi, D.M. (2011) Determination of Heavy Metal Content in Water, Sediment and Micro Algae from Lake Victoria; East Africa. The Open Environmental Engineering journal, 4, 156-161. https://doi.org/10.2174/1874829501104010156

[4] Yi, Y., Yang, Z.F. and Zhang, S.H. (2011) Ecological Risk Assessment of Heavy Metals in Fishes in the Middle and Lower Reaches of the Yangtze River Basin. Journal on Environmental Pollution, 26, 181-188.

[5] Onjefu, S.A., Kgabi, N.A. and Taole, S.H. (2016) Heavy Metal Seasonal Distribution in Shore Sediment Samples along the Coastline of Erongo Region, Western Namibia. European Journal of Scientific Research, 139, 49-63.

[6] Ogwuegbu, M.O. and Duraibe, J.O. (2005) Environmental Pollution and Bio-Toxicity of Certain Heavy Metals. Proceeding of a Conference, Nigeria, 285-287.

[7] Moja, S.J. and Mnisi, J.S. (2013) Seasonal Variations in Airborne Heavy Metals in Vanderbijlpark, South Africa. Journal of Environmental Chemistry and Ecotoxicology, 5, 227-233.

[8] Manju, M. (2015) Effect of Heavy Metals on Human Health. International Journal of Research-Granthaalayah, 31, 1-7.

[9] Chhotu, D. and Fulekar, M. (2009) Phytoremediation of Heavy Metals: Recent Techniques. African Journal of Biotectnology, 8, 921-928.

[10] Anita, Y.P. and Sudkir, K. (2014) Mercury Poisoning; Analytical Aspect with Brief Overview. IIndia Acad Forensic Med., 36, 3.

[11] Sayyed, J. and Bhosle, B. (2010) The Study of Zinc Metal Concentration by Spectrophotometric Method from Godavari River at Nanded, Maharashatra. Pelagia Research Library, USA.

[12] Gunnar, F., Monica, M.M. and Michael, A. (2015) Manganese-Induced Parkinsonism and Parkison's Disease: Share and Distinguishable Features. International Journal of Environmental Research and Public Health, 12, 7519-7540.

[13] Eucharai, O. and Omparkash, D. (2016) Heavy Metals Contaminated Environments and the Road Map with Phytoremediation. Journal of Environment Protection, 7, 41-51. https://doi.org/10.4236/jep.2016.71004

[14] Moller, T., Burmeister, B., Ehresmann, B., Heber, B., Labrenz, J. and Panitzsch, L. (2012) Altitude Dependence of the Dose Rate from Ground up to the Stratosphere. IAEA/INIS Publication, Vienna, Austria.

[15] Terver, S., EJembi, E. and Jonathan, U. (2017) Assessment of Radionuclide Con-tent of Shore Sediments Collected from the Bank of River Benue, North-Central Nigeria. Journal of Geoscience and Environment Protection, 5, 57-65. https://doi.org/10.4236/gep.2017.512004

[16] Ewan, C.A., Anagnostopoulou, M.A. and Ward, N.I. (2009) Monitoring of Heavy Metal Levels in Roadside Dusts of Thessaloniki, Greece in Relation to Motor Vehicle Traffic Density and Flow. 
epubs.surrey.ac.uk/Monitoring_of_Heavy_Metal_Levels_in_Roadside

[17] Abah J., Mashebe, P. and Onjefu, S.A. (2014) Survey of the Level of Heavy Metals in Roadside Dust along Katima Mulilo Urban Road Construction, Namibia. American Journal of Environmental Protection, 3, 19-27. https://doi.org/10.11648/j.ajep.20140301.13

[18] Agency, E.P. (1996) Method 3050B, Acid Digestion of Sediment Sludge and Soils. Environmental Science and Technology, 23, 898.

[19] Foley, R.B. (2011) Urban Geochemical Hazard Mapping of St. John's New Found Land, Canada. Atlantic Geology, 47, 138-157. https://doi.org/10.4138/atlgeol.2011.007

[20] Chiroma, T.M., Ebewele, R.O. and Hymore, F.K. (2014), Comparative Assessment of Heavy Metal Levels in Soil, Vegetables and Urban Grey Waste Water Used for Irrigation in Yola and Kano. International Refereed Journal of Engineering and Science (IRJES), 3, 1-9.

[21] Alfred, S.L., Khumoetsile, B.M. and Gilbert, K.G. (2013) Assessment of Heavy Metal Enrichment and Degree of Contamination around the Copper-Nickel Mine in the Selebi Phikwe Region, Eastern Botswana. Environmental and Ecology Research, 1, 32-40.

[22] Nikulina, A. and Dullo, W.C. (2009) Eutrophication and Heavy Metal Pollution in the Flensburg Fjord: A Reassessment after 30 Years. Marine Pollution Bulletin, 58, 905-915. https://doi.org/10.1016/j.marpolbul.2009.01.017

[23] Aboud, S.J. and Nandini, N. (2009) Heavy Metal Analysis and Sediment Quality Values in Urban Lakes. American Journal of Environmental Science, 5, 678-687. https://doi.org/10.3844/ajessp.2009.678.687

[24] Ogbeibu, A.O. (2014) Using Pollution Load Index and Geoaccumulation Index for the Assessment of Heavy Metal Pollution and Sediment Quality of Benin River, Nigeria. Natural Environment, 11, 1-9.

[25] Saikia, B.G. (2014) Estimation of Heavy Metals Contamination and Silicate Mineral Distributions in Suspended Sediments of Subansiri River. International Journal of Physical Sciences, 9, 475-486.

[26] Hu, Q.W. (2010) Sources of Anthropogenic Radionuclides in the Environment: a Review. Journal of Environmental Radioactivity, 101, 426-437. https://doi.org/10.1016/j.jenvrad.2008.08.004

[27] Tomlinson, D., Wilson, J., Harris, C. and Jeffrey, D. (1980) Problems in the Assessment of Heavy Metal Levels in Estuarine and the Formation of a Pollution Index. Helgoland Marine Resources, 33, 566-575. 